\title{
Solusi Persamaan Difusi Menggunakan Metode Transformasi Laplace Diferensial dan Perilakunya Terhadap Solusi Eksak
}

\author{
Dody Jesaya Sinaga, Endang Rusyaman, Edi Kurniadi \\ Departemen Matematika, Fakultas MIPA Universitas Padjadjaran, \\ dody16001@mail.unpad.ac.id, rusyaman@unpad.ac.id, edi.kurniadi@unpad.ac.id
}

\begin{abstract}
Abstrak
Persamaan diferensial adalah salah satu kajian matematika terbesar di bidang kalkulus. Umumnya persamaan diferensial dibagi menjadi dua bentuk, yaitu persamaan diferensial biasa dan persamaan diferensial parsial. Selain itu, perkembangan studi persamaan diferensial tidak terbatas pada orde bilangan asli, namun berkembang pada orde bilangan fraksional, yang disebut persamaan diferensial fraksional. Ada beberapa metode untuk memperoleh solusi dari persamaan diferensial parsial fraksional, salah satunya adalah metode transformasi Laplace Diferensial yang melibatkan dua transformasi, yaitu transformasi Laplace dan transformasi diferensial. Penulis mencoba menyelesaikan persamaan salah satu diferensial parsial fraksional, yaitu persamaan difusi menggunakan metode transormasi Laplace diferensial. Selanjutnya, barisan orde dari persamaan difusi dapat diamati konvergensinya ke suatu bilangan yang mengakibatkan barisan fungsi solusi dari persaamaan difusi akan konvergen ke fungsi solusi dengan orde bilangan itu sendiri. Selanjutnya, penulis memperlihatkan perilaku solusi aproksimasi terhadap solusi eksaknya yang menunjukkan adanya beberapa faktor yang memengaruhi nilai galatnya.

Kata Kunci: Persamaan Difusi, Metode Transformasi Laplace Diferensial, Konvergensi, Perilaku, Galat.
\end{abstract}

\begin{abstract}
Differential equations is one of the biggest study in calculus field. Generally, differential equations consist of two forms, i.e. ordinary differential equations and partial differential equations. Besides that, propagation study in differential equations are not bounded on integer order, but develop on fractional order, i.e. fractional differential equations. There are several method to obtain the solution of fractional partial differential equations, one of them is Laplace Differential Transform Method which involves two transformations, namely Laplace transformation and differential transformation. The author attempts to solve one of the fractional partial differential equation, namely diffusion equation using method mentioned. Next, the order of the diffusion equation can be observed for its convergence to a number which results in the sequence of the solution function of the diffusion equation converge to the solution function with order of that number itself. Furthermore, the author shows the behaviour of the approximation solution to its exact solution which shows that there are several factors that effects the error. Keywords: diffusion equation. Laplace differential transformation method, convergence, behaviour, error.
\end{abstract}




\section{Pendahuluan}

Banyak sekali fenomena di dunia yang dapat dimodelkan menjadi suatu model matematika. Salah satu alat pada matematika yang banyak bermanfaat untuk memodelkan suatu fenomena adalah persamaan diferensial. Persamaan diferensial adalah suatu persamaan yang melibatkan satu variabel tak bebas dan turunannya terhadap satu atau lebih variabel bebas. Persamaan diferensial dibagi menjadi dua bagian, yaitu persamaan diferensial biasa dan persamaan diferensial parsial. Umumnya pada persamaan diferensial, turunan-turunan pada suatu variabel tak bebasnya adalah turunan ke- $n$ dengan $n$ merupakan bilangan bulat positif. Namun, turunan pada persamaan diferensial dapat diperumum menjadi turunan ke- $\alpha$ dengan $\alpha$ merupakan bilangan real positif, sehingga berkembanglah persamaan diferensial fraksional. Kajian ini dipelopori oleh Gottfried Wilhem Leibniz dan Guillaume François Antoine de l'Hôpital pada tahun 1695. Sejak saat itu, berkembanglah definisi turunan fraksional dari beberapa matematikawan, beberapa di antaranya adalah Riemann-Liouville [11], Grünwald-Letnikov [12], dan Caputo [13]. Metode yang digunakan dalam penyelesaian persamaan diferensial dengan turunan fraksional (selanjutnya disebut persamaan diferensial fraksional) mengalami perkembangan dengan menggunakan pendekatan yang variatif, beberapa di antaranya adalah Differential Transformation Method [10], Sumudu Transformation Method [14], Variational Iteration Method [15], dan Homotopy Analysis Method [16]. Beberapa manfaat persamaan diferensial fraksional adalah pemodelan pertumbuhan ekonomi suatu negara pada [1], epidemiologi pada [2] dan lain-lain.

Terdapat beberapa peneliti yang meneliti tentang metode hibrida, yaitu transformasi Laplace diferensial (MTLD) sebagai metode dalam mencari solusi persamaan diferensial. Metode ini menggunakan dua transformasi yang berbeda, yaitu transformasi Laplace dan transformasi diferensial. Beberapa di antaranya seperti pada [3] pada kasus persamaan diferensial parsial non-homogen dan [4] yang pertama kali menggunakannya pada kasus persamaan diferensial parsial fraksional. Pada jurnal ini, Penulis juga menggunakan MTLD dalam mencari solusi persamaan difusi berorde fraksional. Namun berbeda dengan jurnal [3] dan [4], pada jurnal ini selanjutnya dianalisis kekonvergenan barisan fungsi solusi, serta diperlihatkan perilaku solusi aproksimasinya dengan solusi eksaknya. Persamaan difusi memiliki bentuk sebagai berikut

$$
\frac{\partial^{\alpha} u(x, t)}{\partial t^{\alpha}}-\mu \frac{\partial^{2} u(x, t)}{\partial x^{2}}=0,0<\alpha \leq 1, \mu \text { konstanta real }
$$

dengan kondisi awal yang diberikan.

\section{Metode Penelitian}

2.1. Pengantar singkat dan definisi dasar. Pada bagian ini akan dipaparkan beberapa definisi dasar yang diperlukan dalam penelitian ini. Beberapa di antaranya adalah sebagai berikut

Definisi 2.1. Menurut [7] Integral fraksional Riemann-Liouville dengan orde $\alpha>0$ dan $t>a$ didefinisikan sebagai

$$
R L^{J^{\alpha}} f(t)=\frac{1}{\Gamma(\alpha)} \int_{a}^{t}(t-\tau)^{\alpha-1} f(\tau) d \tau
$$

Definisi 2.2. Menurut [7] Turunan fraksional Caputo dengan orde $\alpha>0, t>a$, dan $n-1<$ $\alpha \leq n, n \in \mathbb{N}$ didefinisikan sebagai

$$
{ }_{C} J^{\alpha} f(t)=\frac{1}{\Gamma(n-\alpha)} \int_{a}^{t}(t-\tau)^{n-\alpha-1} f^{(n)}(\tau) d \tau .
$$

Definisi 2.3. Menurut [8] Fungsi Mittag-Leffler satu parameter dapat ditulis sebagai

$$
E_{\alpha}(z)=\sum_{k=0}^{\infty} \frac{z^{k}}{\Gamma(\alpha k+1)}, \alpha>0, z \in \mathbb{C}
$$


2.2. Transformasi Laplace. Secara umum, transformasi Laplace adalah suatu transformasi integral dari suatu fungsi dengan variabel real $t$ (umumnya waktu) ke suatu fungsi dengan variabel kompleks $s$.

Definisi 2.4. Menurut [9] Misalkan $f$ adalah fungsi bernilai real atau kompleks dari (waktu) variabel $t>0$ dan $s$ adalah parameter real atau kompleks. Transformasi Laplace dari f adalah

$$
F(s)=\mathcal{L}[f(t)]=\lim _{\tau \rightarrow \infty} \int_{0}^{\tau} e^{-s t} f(t) d t
$$

Teorema 2.5. Menurut [7] Jika $F(s)$ adalah transformasi Laplace dari $f(t)$, maka transformasi Laplace dari operator turunan fraksional Caputo dengan orde $\alpha>0$ dapat ditulis sebagai

$$
\mathcal{L}\left[{ }_{C} J^{\alpha} f(t)\right]=s^{\alpha}-\sum_{i=0}^{n-1} s^{\alpha-i-1} f^{(i)}(0), n-1<\alpha<n
$$

Beberapa bentuk transformasi Laplace dari suatu fungsi yang adalah sebagai berikut

TABEL 1. Transformasi Laplace

\begin{tabular}{llllll}
\hline No. & $f(t)$ & $F(s)$ & No. & $f(t)$ & $F(s)$ \\
\hline 1. & 1 & $\frac{1}{s}$ & 4. & $e^{a t}$ & $\frac{1}{s-a}$ \\
2. & $t^{n}$ & $\frac{n !}{s^{n+1}}$ & 5. & $t^{n} e^{a t}$ & $\frac{n !}{(s-a)^{n+1}}$ \\
3. & $E_{\alpha}\left(t^{\alpha}\right)$ & $\frac{s^{\alpha-1}}{s^{\alpha}-1}$ & 6. & $\frac{t^{\alpha}}{\Gamma(\alpha+1)}$ & $\frac{1}{s^{\alpha+1}}$ \\
\hline
\end{tabular}

2.3. Transformasi Diferensial. Menurut [10] Diberikan fungsi $u(x)$ yang analitik dan diferensiabel pada domainnya. Transformasi diferensial dari turunan ke- $k$ dari $u(x)$ didefinisikan sebagai

$$
U(k)=\frac{1}{k !}\left[\frac{d^{k} u(x)}{d x^{k}}\right]_{x=x_{0}}
$$

Diberikan fungsi $U(k)$ yang merupakan transformasi diferensial dari $u(x)$. Invers transformasi diferensial dari $U(k)$ didefinisikan sebagai

$$
u(x)=\sum_{k=0}^{\infty} U(k)\left(x-x_{0}\right)^{k}
$$

Dengan persamaan (7) dan (8) maka diperoleh:

$$
u(x)=\sum_{k=0}^{\infty} \frac{1}{k !}\left[\frac{d^{k} u(x)}{d x^{k}}\right]_{x=x_{0}}\left(x-x_{0}\right)^{k}
$$

Beberapa operasi/sifat transformasi diferensial yang digunakan pada penelitian ini adalah sebagai berikut

2.4. Metode Transformasi Laplace Diferensial. Pada bagian ini dibahas tentang pencarian solusi dari persamaan diferensial parsial fraksional menggunakan MTLD dengan bentuk umum persamaan difusi fraksional yang digunakan adalah sebagai berikut

$$
\frac{\partial^{\alpha} u(x, t)}{\partial t^{\alpha}}-\mu \frac{\partial^{2} u(x, t)}{\partial x^{2}}=0,0<\alpha \leq 1, \mu \text { konstanta real }
$$

dengan kondisi awal yang diberikan.

Metode Transformasi Laplace Diferensial (MTLD) adalah metode hibrida dari dua metode transformasi yang berbeda, yaitu metode transformasi Laplace dan transformasi diferensial. MTLD merupakan metode numerik-analitik yang dapat menyelesaikan persamaan diferensial parsial fraksional (PDPF). Ide utama dari MTLD adalah mengubah PDPF menjadi persamaan 
TABEL 2. Sifat Transformasi Diferensial

\begin{tabular}{lll}
\hline No. & fungsi awal & fungsi transformasi \\
\hline 1. & $u(x)=w(x) \pm v(x)$ & $U(k)=W(k) \pm V(k)$ \\
2. & $u(x)=c w(x)$ & $U(k)=c W(k)$ \\
3. & $u(x)=e^{\lambda x}$ & $U(k)=\frac{\lambda^{k}}{k !}$ \\
4. & $u(x)=w(x) v(x)$ & $U(k)=\sum_{r=0}^{k} W(r) V(k-r)$ \\
5. & $u(x)=\frac{d^{n}}{d x^{n}} v(x)$ & $\frac{(k+n) !}{k !} V(k+n)$ \\
6. & $u(x)=x^{n}$ & $U(k)=\delta(k-n)= \begin{cases}1, & k=n \\
0, & \text { lainnya }\end{cases}$ \\
\hline
\end{tabular}

diferensial biasa (PDB) dengan metode transformasi Laplace, lalu mencari solusi dari PDB tersebut menggunakan metode transformasi diferensial. Keunggulan dari metode ini adalah kesederhanannya dalam komputasi numeriknya.

Prosedur pencarian solusi dari PDPF menggunakan MTLD adalah sebagai berikut:

Terapkan transformasi Laplace di kedua ruas pada PDPF dan pada kondisi awal yang diberikan terhadap variabel $t$ sehingga menjadi sebagai berikut

$$
\mathcal{L}\left[\frac{\partial^{\alpha} u(x, t)}{\partial t^{\alpha}}-\mu \frac{\partial^{2} u(x, t)}{\partial x^{2}}\right]=\mathcal{L}[0]
$$

Hal yang sama diperlakukan pula pada kondisi awal dari PDPF tersebut. Dengan memisalkan $\mathcal{L}[u(x, t)]=\bar{u}(x, s)$, maka bentuk (11) menjadi lebih sederhana sebagai berikut

$$
-\mu \frac{d^{2} \bar{u}(x, s)}{d x^{2}}+s^{\alpha} \bar{u}(x, s)=-s^{\alpha-1} u(x, 0)
$$

Setelah itu, terapkan transformasi diferensial pada setiap suku pada (12) dan kondisi awalnya terhadap variabel $x$ sehingga diperoleh

$$
-\mu(k+2)(k+1) U(k+2)+s^{\alpha} U(k)=-s^{\alpha-1} Q(k)
$$

Dengan $U(k)$ adalah fungsi rekursif dan $Q(k)$ adalah hasil transformasi diferensial $u(x, 0)$. Seperti yang telah disebutkan di awal, bahwa kondisi awal dari PDPF ini diperlakukan sama seperti PDPFnya, sedemikian sehingga kondisi awal yang telah ditransformasikan Laplace dan diferensial ini akan menghasilkan $U(k), k=0,1$. Dari $U(k), k=0,1$ diperoleh $U(k), k=2,3,4$, . Setelah diperoleh nilai-nilai tersebut, maka dapat diterapkan invers transformasi Laplace terhadap $k$ dengan bentuk:

$$
\bar{u}(x, s)=\sum_{k=0}^{\infty} U(k) x^{k} .
$$

Lalu, terapkan kembali invers transformasi Laplace terhadap variabel $s$ dari kedua ruas maka diperoleh $u(x, t)$ yang merupakan solusi aproksimasi dari (10) dengan menggunakan MTLD.

\section{Hasil dan Pembahasan}

Pembahasan mengenai hasil utama dibahas disini. Definisi, Lemma, Teorema, Proposisi, Akibat dan Contoh dapat disajikan dalam format berikut. 
3.1. Persamaan Diferensial Parsial Fraksional Orde $\alpha$ dengan $\mu=1$. Diberikan persamaan diferensial parsial fraksional linear homogen berorde $\alpha$ berikut

$$
\frac{\partial^{\alpha} u(x, t)}{\partial t^{\alpha}}-\frac{\partial^{2} u(x, t)}{\partial x^{2}}=0,0<\alpha \leq 1
$$

dengan kondisi awal

$$
\left\{\begin{array}{l}
u(x, 0)=\sin (x) \\
u(0, t)=0 \\
u_{x}(0, t)=E_{\alpha}\left(-t^{\alpha}\right)
\end{array}\right.
$$

Pencarian solusi dari persamaan difusi berorde $\alpha$ menggunakan Metode Transformasi Laplace Diferensial (MTLD) sebagai berikut Terapkan transformasi Laplace pada (15) dan (16) terhadap variabel $t$ sehingga

$$
\mathcal{L}\left[\frac{\partial^{\alpha} u(x, t)}{\partial t^{\alpha}}\right]-\mathcal{L}\left[\frac{\partial^{2} u(x, t)}{\partial x^{2}}\right]=\mathcal{L}[0]
$$

dengan kondisi awal

$$
\left\{\begin{array}{l}
\mathcal{L}[u(x, 0)]=\mathcal{L}[\sin (x)] \\
\mathcal{L}[u(0, t)]=\mathcal{L}[0] \\
\mathcal{L}\left[u_{x}(0, t)\right]=\mathcal{L}\left[E_{\alpha}\left(-t^{\alpha}\right)\right]
\end{array}\right.
$$

Dengan menggunakan sifat-sifat transformasi Laplace dan memisalkan $\mathcal{L}[u(x, t)]=\bar{u}(x, s)$, maka diperoleh

$$
-\frac{d^{2} \bar{u}(x, s)}{d x^{2}}+s^{\alpha} \bar{u}=s^{\alpha-1} \sin (x)
$$

dengan kondisi awal menjadi

$$
\bar{u}(0, s)=0, \quad \frac{d}{d x} \bar{u}(0, s)=\frac{s^{\alpha-1}}{s^{\alpha}+1} .
$$

Perhatikan bahwa dengan transformasi Laplace, persamaan difusi berubah menjadi PDB dengan kondisi awal yang telah ditransformasikan juga. Setelah itu, aplikasikan transformasi diferensial (19) dan (20) terhadap variabel $x$ (dalam hal ini variabel $s$ menjadi konstanta) sehingga diperoleh

$$
U(k+2)=\frac{1}{(k+2)(k+1)}\left[s^{\alpha} U(k)-\frac{s^{\alpha-1}}{k !} \sin \left(\frac{k \pi}{2}\right)\right]
$$

dengan

$$
U(0)=0, \quad U(1)=\frac{s^{\alpha-1}}{s^{\alpha}+1} .
$$

Dengan menggunakan (22), maka (21) akan diperoleh bentuk eksplisitnya, dalam hal ini $U(k), k=2,3,4, \ldots$, sehingga dalam bentuk (8), yaitu invers transformasi diferensial, maka diperoleh

$$
\begin{gathered}
\bar{u}(x, s)=\sum_{k=0}^{\ell} U(k) x^{k} \\
\bar{u}(x, s)=\frac{s^{\alpha-1}}{s^{\alpha}+1}\left(\frac{1}{1 !} x-\frac{1}{3 !} x^{3}+\frac{1}{5 !} x^{5}-\frac{1}{7 !} x^{7}+\ldots\right) .
\end{gathered}
$$

Dengan mengambil invers transformasi Laplace terhadap variabel $s$ dari (24), maka diperoleh solusi aproksimasi

$$
\begin{gathered}
u(x, t)=E_{\alpha}\left(-t^{\alpha}\right)\left(\frac{1}{1 !} x-\frac{1}{3 !} x^{3}+\frac{1}{5 !} x^{5}-\frac{1}{7 !} x^{7}+\ldots\right) . \\
u(x, t)=E_{\alpha}\left(-t^{\alpha}\right) \sum_{n=0}^{\ell} \frac{(-1)^{n} x^{2 n+1}}{(2 n+1) !} .
\end{gathered}
$$


3.2. Analisis Kekonvergenan Barisan Fungsi Solusi Persamaan Difusi. Setelah memperoleh solusi aproksimasi persamaan difusi menggunakan MTLD, diperlihatkan kekonvergenan barisan fungsi solusi aproksimasi orde $\alpha_{n}$ dengan memilih suatu barisan bilangan real $\left(\alpha_{n}\right)=\frac{n+1}{n+3}$, maka persamaan difusi orde $\alpha_{n}$ menjadi

$$
\frac{\partial^{\frac{n+1}{n+3}} u(x, t)}{\partial t^{\frac{n+1}{n+3}}}-\frac{\partial^{2} u(x, t)}{\partial x^{2}}=0, n \in \mathbb{N},
$$

sehingga diperoleh barisan fungsi solusi persamaan difusi berorde $\alpha_{n}$, dinotasikan dengan $u_{n}(x, t)$ sebagai berikut

$$
u_{n}(x, t)=E_{\frac{n+1}{n+3}}\left(-t^{\frac{n+1}{n+3}}\right)\left(\frac{1}{1 !} x-\frac{1}{3 !} x^{3}+\frac{1}{5 !} x^{5}-\frac{1}{7 !} x^{7}+\ldots\right) .
$$

Selanjutnya diperlihatkan bahwa barisan fungsi $\left(u_{n}(x, t)\right)$ konvergen ke $u(x, t)$, di mana $u(x, t)$ adalah solusi aproksimasi persamaan difusi orde $\alpha=1$.

$$
\begin{aligned}
u(x, t)=E_{1}(-t)\left(\frac{1}{1 !} x-\frac{1}{3 !} x^{3}+\frac{1}{5 !} x^{5}-\frac{1}{7 !} x^{7}+\ldots\right) \\
\lim _{n \rightarrow \infty}=\lim _{n \rightarrow \infty} E_{\frac{n+1}{n+3}}\left(-t^{\frac{n+1}{n+3}}\right)\left(\frac{1}{1 !} x-\frac{1}{3 !} x^{3}+\frac{1}{5 !} x^{5}-\frac{1}{7 !} x^{7}+\ldots\right) \\
=E_{1}(-t)\left(\frac{1}{1 !} x-\frac{1}{3 !} x^{3}+\frac{1}{5 !} x^{5}-\frac{1}{7 !} x^{7}+\ldots\right) \\
=u(x, t)
\end{aligned}
$$

Dengan menggunakan software Maple 18, dapat digambarkan grafik di bidang $\mathbb{R}^{2}$ dengan variabel $x$ dan $t$ terhadap fungsi solusi persamaan difusi untuk beberapa orde, yaitu $\alpha_{1}, \alpha_{2}$, $\alpha_{3}, \alpha_{4}, \alpha_{5}, \alpha_{6}, \alpha_{7}, \alpha_{99}$, dan $\alpha$ sebagai berikut.
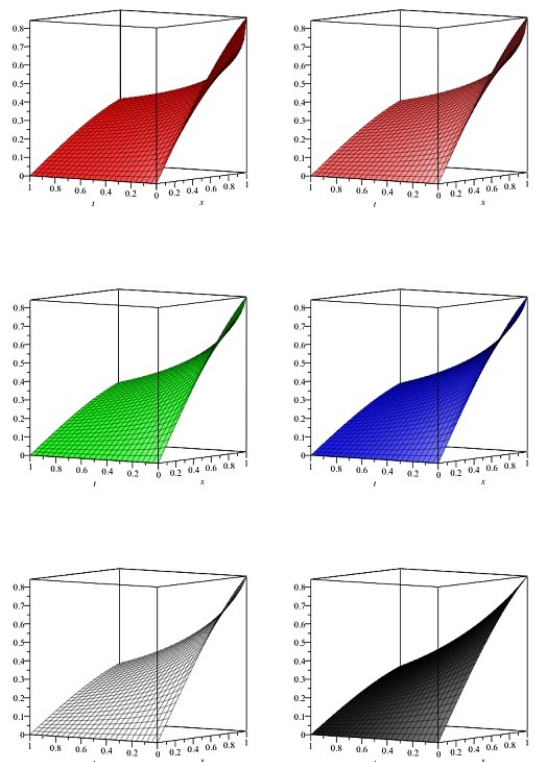

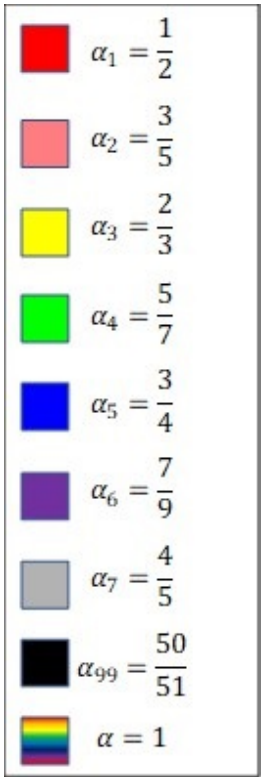

Gambar 1. Grafik setiap fungsi solusi $\frac{\partial^{\alpha} u(x, t)}{\partial t^{\alpha}}-\frac{\partial^{2} u(x, t)}{\partial x^{2}}=0$ pada orde $\left(\alpha_{n}\right)=\left(\frac{n+1}{n+3}\right)$

Dengan menggunakan software Maple 18, jika sembilan grafik tersebut ditumpuk pada satu bidang $\mathbb{R}^{2}$ dengan variabel $x$ dan $t$, maka dapat diamati kekonvergenannya dengan pendekatan grafik, yaitu Gambar 2. 


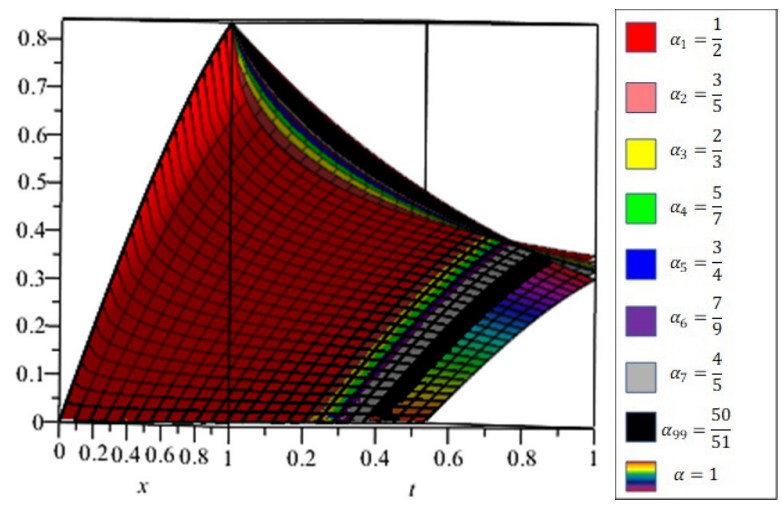

Gambar 2. Grafik fungsi solusi $\frac{\partial^{\alpha} u(x, t)}{\partial t^{\alpha}}-\frac{\partial^{2} u(x, t)}{\partial x^{2}}=0$ dengan orde $\left(\alpha_{n}\right)=\left(\frac{n+1}{n+3}\right)$

Berdasarkan Gambar 2, selain dengan menganalisis kekonvergenan barisan fungsinya dengan pendekatan limit, hasil secara grafik menunjukkan bahwa pola bidang yang dihasilkan bergerak menuju bidang yang merupakan solusi persamaan difusi dengan $\alpha=1$. Maka terbukti bahwa dengan memilih barisan bilangan real dengan $0<\alpha_{n}<1$ dan konvergen ke $\alpha=1$, maka akan menghasilkan barisan fungsi persamaan difusi dengan orde $\alpha_{n}$ dan barisan fungsi dari solusi persamaan difusi dengan orde $\alpha_{n}$ akan konvergen ke $\alpha=1$.

3.3. Perilaku Solusi Aproksimasi Persamaan Difusi dengan Solusi Eksaknya. Setelah menentukan solusi aproksimasi persamaan difusi menggunakan MTLD, diperlihatkan bagaimana perilaku solusi aproksimasi ini terhadap solusi eksaknya. Solusi eksak dari (15) dan (16) adalah $u_{\text {exact }}(x, t)=e^{-t} \sin (x)$. Dengan menggunakan prinsip integral lipat dua pada selisih antara solusi aproksimasi dan solusi eksaknya dengan pendekatan mean absolute error, maka diperoleh suatu fungsi galat total (FGT) sebagai

$$
\mathrm{FGT}=\int_{c}^{d} \int_{a}^{b}\left|u(x, t)-u_{\text {exact }}(x, t)\right| d x d t .
$$

Sehingga, persamaan (30) pada kasus ini dapat ditulis sebagai

$$
\mathrm{FGT}=\int_{c}^{d} \int_{a}^{b}\left|e^{-t} \sum_{n=0}^{\ell} \frac{(-1)^{n} x^{2 n+1}}{(2 n+1) !}-e^{-t} \sin (x)\right| d x d t .
$$

Akhirnya diperoleh Fungsi Galat Total (FGT), yaitu adalah suatu fungsional dengan pemetaan $\varepsilon: \mathbb{W} \times \mathbb{R}^{2} \times \mathbb{R}^{2} \rightarrow \mathbb{R}$, yaitu $\varepsilon:(\ell,(a, b),(c, d)) \rightarrow e$ dengan $b>a$ dan $d>c$ sebagai

$$
\varepsilon:(\ell,(a, b),(c, d))= \begin{cases}\left(\left(\sum_{n=0}^{\ell} \frac{(-1)^{n} b^{2 n+2}}{(2 n+2) !}-\sum_{n=0}^{\ell} \frac{(-1)^{n} a^{2 n+2}}{(2 n+2) !}\right)+\right. & \\ (\cos (b)-\cos (a)))\left(e^{-c}-e^{-d}\right), & \ell=2 k, k \in \mathbb{W} \\ \left(\left(\sum_{n=0}^{\ell} \frac{(-1)^{n} a^{2 n+2}}{(2 n+2) !}-\sum_{n=0}^{\ell} \frac{(-1)^{n} b^{2 n+2}}{(2 n+2) !}\right)+\right. & \\ (\cos (a)-\cos (b)))\left(e^{-c}-e^{-d}\right), & \ell=2 k+1, k \in \mathbb{W}\end{cases}
$$

Nilai $\ell, a, b, c, d$ pada (32) dapat diatur sedemikan rupa sehingga didapat nilai galat dari fungsional yang telah ditentukan.

Berikut adalah beberapa perilaku solusi aproksimasi persamaan difusi terhadap solusi eksaknya dengan mempertimbangkan orde deret taylor $\ell$, batas bawah $a$ dan batas bawah $b$ 
untuk variabel $x$, dan batas bawah $c$ dan batas atas $d$ untuk variabel $t$, dengan menyubstitusikan nilai-nilainya ke Persamaan (32).

1. Untuk $\ell=8,0<t \leq 7,0<x \leq 7$, maka nilai galatnya adalah:

$$
\begin{aligned}
\varepsilon(8,(0,7),(0,7)) & =\left(\left(\sum_{n=0}^{8} \frac{(-1)^{n} 7^{2 n+2}}{(2 n+2) !}-\sum_{n=0}^{8} \frac{(-1)^{n} 0^{2 n+2}}{(2 n+2) !}\right)+(\cos (7)-\cos (0))\right)\left(e^{0}-e^{-7}\right) \\
& \approx 0,02957860199
\end{aligned}
$$

Jadi, nilai galat yang dihasilkan solusi aproksimasi terhadap solusi eksaknya dengan orde deret taylor $\ell=8$ pada interval: $0 \leq x \leq 7,0<t \leq 7$ adalah sekitar 0,02957860199 .

Apabila digambarkan dalam bentuk grafik, maka perbandingan antara solusi aproksimasi dengan menggunakan MTLD dengan solusi eksaknya dapat digambarkan dengan software Maple 18 sebagai berikut:

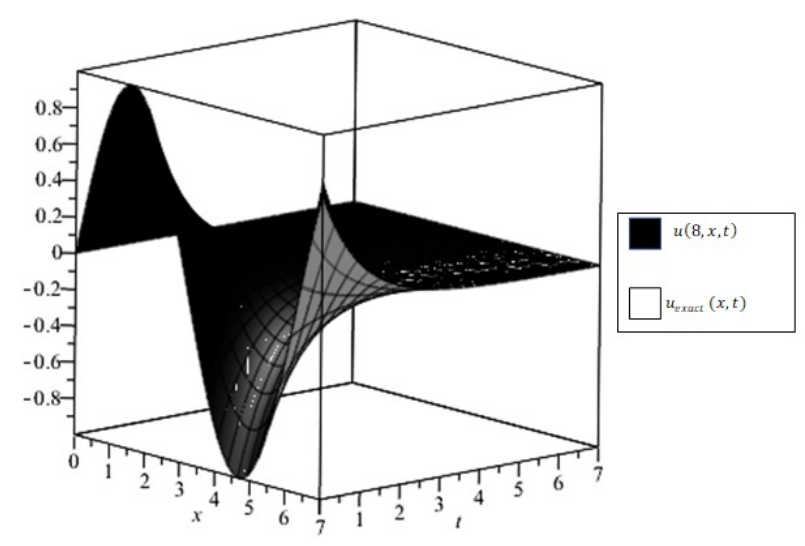

GAmbar 3. Grafik solusi aproksimasi dan solusi eksak dari persamaan difusi dengan orde 8 pada interval $0 \leq x \leq 7,0<t \leq 7$

Dengan nilai galat sebesar 0,02957860199 dan bentuk grafik yang hampir berimpit satu sama lain, maka secara numerik dan grafik bahwa solusi aproksimasi yang dihasilkan menggunakan MTLD memiliki hasil aproksimasi yang sangat baik. Jika orde $\ell$ diperbesar, maka galat yang dihasilkan makin kecil dan aproksimasi lebih baik. Perhatikan (26) bahwa untuk $\ell \rightarrow \infty$, maka deret pangkat $\sum_{n=0}^{\ell} \frac{(-1)^{n} x^{2 n+1}}{(2 n+1) !}$ merupakan deret Taylor fungsi trigonometri $\sin (x)$ untuk $x$ di sekitar $x=0$ atau disebut deret MacLaurin fungsi trigonometri $\sin (x)$. Karena $\sum_{n=0}^{\infty} \frac{(-1)^{n} x^{2 n+1}}{(2 n+1) !}=\sin (x)$ maka $u(\infty, x, t)=u_{\text {exact }}(x, t)$ yang akhirnya jika $\ell \rightarrow \infty$, maka $\varepsilon(\infty,(0,7),(0,7))=0$. Atau secara umum, $\varepsilon(\infty,(a, b),(c, d))=0$ untuk $b>a, d>c$.

2. Untuk $\ell=10$ dan $11,0<t \leq 3 \pi, 0<x \leq 3 \pi$, maka nilai galatnya adalah:

$$
\begin{aligned}
\varepsilon(10,(0,3 \pi),(0,3 \pi)) & =\left(\left(\sum_{n=0}^{10} \frac{(-1)^{n}(3 \pi)^{2 n+2}}{(2 n+2) !}-\sum_{n=0}^{10} \frac{(-1)^{n} 0^{2 n+2}}{(2 n+2) !}\right)+(\cos (3 \pi)-\cos (0))\right)\left(e^{0}-e^{-3 \pi}\right) \\
& \approx 0,3413568280 \\
\varepsilon(11,(0,3 \pi),(0,3 \pi)) & =\left(\left(\sum_{n=0}^{11} \frac{(-1)^{n} 0^{2 n+2}}{(2 n+2) !}-\sum_{n=0}^{11} \frac{(-1)^{n}(3 \pi)^{2 n+2}}{(2 n+2) !}\right)+(\cos (0)-\cos (3 \pi))\right)\left(e^{0}-e^{-3 \pi}\right) \\
& \approx 0,04747796136 .
\end{aligned}
$$

Jadi galat, yang dihasilkan solusi aproksimasi terhadap solusi eksaknya pada interval $0 \leq x \leq 3 \pi, 0<t \leq 3 \pi$ dengan orde $\ell=10$ dan 11 berturut-turut adalah sekitar 0,3413568280 dan 0,04747796136 . 
Adapun jika digambarkan dalam bentuk grafik menggunakan software Maple 18, maka perbandingan antara solusi aproksimasi dengan menggunakan MTLD dengan solusi eksaknya dapat digambarkan sebagai berikut:

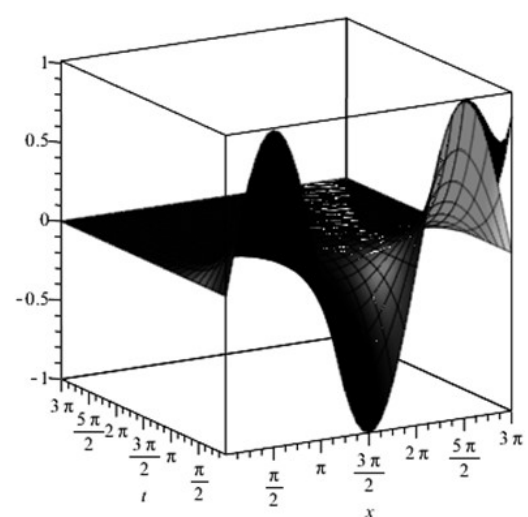

(a)

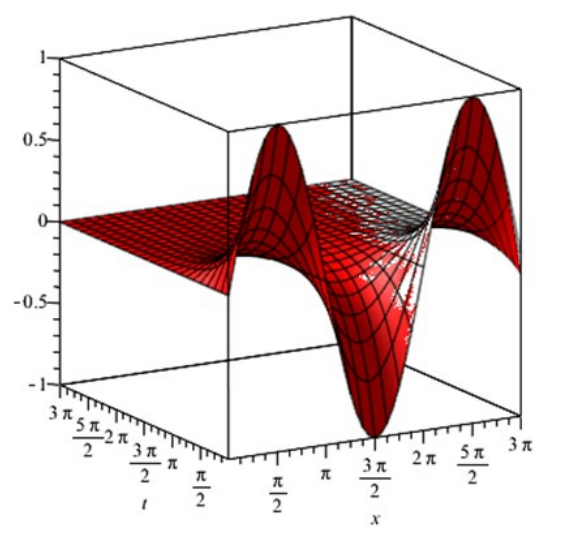

(b)

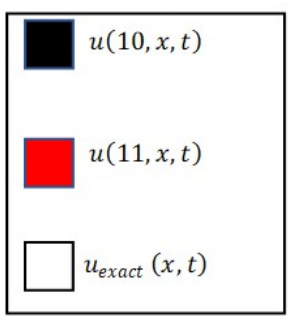

Gambar 4. Grafik solusi aproksimasi dan solusi eksak dari persamaan difusi dengan orde 10 dan 11 pada interval $0 \leq x \leq 3 \pi, 0<t \leq 3 \pi$

Tampak pada Gambar 4 bahwa untuk $\ell$ yang berbeda, memberikan hasil yang berbeda. Pada grafik (a), kedua grafik cukup berimpit namun terdapat ruang (dalam hal ini adalah galat) antara solusi aproksimasi dengan solusi eksaknya $x \in\left[\frac{5 \pi}{2}, 3 \pi\right]$. Sedangkan pada grafik (b), solusi aproksimasi dan solusi eksaknya telah berimpit satu sama lain pada interval tersebut. Didukung dengan hasil numerik untuk nilai galatnya bahwa perubahan $\ell$ memberikan perbedaan yang cukup signifikan. Untuk $\ell$ yang lebih besar, maka deret pangkat yang diperoleh lebih kompleks karena suku pangkatnya yang lebih banyak dan menambah tingkat kesulitan komputasi. Namun, grafik yang dihasilkan akan mendekati solusi eksaknya dan memberikan nilai galat yang lebih kecil. Secara keseluruhan, perilaku solusi aproksimasi dan solusi eksaknya dapat dipengaruhi oleh interval $x$, interval $t$, dan orde deret taylor $\ell$. Namun, untuk sembarang interval, jika orde deret taylor $\ell \rightarrow \infty$, maka solusi aproksimasi akan menjadi sama dengan solusi eksaknya sehingga tidak ada selisih antara kedua fungsi tersebut yang mengakibatkan galat menjadi sama dengan nol. Jika dirangkum dalam bentuk tabel, maka diperoleh sebagai berikut: 
TABel 3. Tabel Perbandingan Hasil Numerik

\begin{tabular}{|c|c|c|c|c|}
\hline \multicolumn{1}{|c|}{ interval } & $0 \leq x \leq 7$ & $0 \leq x \leq 7$ & $0 \leq x \leq 3 \pi$ & $0 \leq x \leq 3 \pi$ \\
orde & $0 \leq t \leq 7$ & $0 \leq t \leq 3 \pi$ & $0 \leq t \leq 7$ & $0 \leq t \leq 3 \pi$ \\
\hline 8 & 0,02957860199 & 0,02960321002 & 10,48417176 & 10,49289406 \\
10 & 0,00028666756 & 0,00028690602 & 0.3410739164 & 0,341356828 \\
11 & 0,00002182958 & 0.00002184780 & 0.0474387475 & 0.047477547 \\
$\vdots$ & $\vdots$ & $\vdots$ & $\vdots$ & $\vdots$ \\
$\infty$ & 0 & 0 & 0 & 0 \\
\hline
\end{tabular}

\section{Simpulan}

Solusi dari persamaan diferensial parsial fraksional, dalam hal ini adalah persamaan difusi, dapat ditentukan dengan metode transformasi Laplace diferensial. Lalu, untuk suatu barisan bilangan real $\left(\alpha_{n}\right)$ yang konvergen ke $\alpha$ maka barisan fungsi solusi persamaan difusi berorde $\alpha_{n}$ akan konvergen ke solusi persamaan difusi dengan orde $\alpha$ melalui pendekatan limit dan grafik. Selain itu, perilaku solusi aproksimasi persamaan difusi terhadap solusi eksaknya dipengaruhi oleh orde dari deret pangkat, batas interval $x$ dan batas interval $t$ dengan catatan besarnya orde pangkat berbanding terbalik dengan besarnya galat yang dihasilkan, dan besarnya interval $x$ dan $t$ berbanding lurus dengan besarnya galat yang dihasilkan. Beberapa hasil numerik dan komparasinya diberikan sebagai simulasi dengan menggunakan Maple 18. Pendekatan galat yang digunakan adalah mean absolute error dan integral lipat dua.

\section{Daftar Pustaka}

[1] Tejado, I., et al., 2015, Fractional calculus in economic growth modelling: the Spanish and Portuguese cases, International Journal of Dynamics and Control, Vol. 5(1), pp. 208-222.

[2] Singh, J., et al., 2018, A fractional epidemiological model for computer viruses pertaining to a new fractional derivative, Applied Mathematics and Computation, Vol. 316, pp. 504-515.

[3] Alquran, M., et al., 2012, The Combined Laplace Transform-Differential Transform Method For Solving Linear Non-Homogeneous PDES, Journal of Mathematical and Computational Science, Vol. 2(3), pp. 690701.

[4] Özkan, O., Kurt, A., 2019, A new method for solving fractional partial differential equations, The Journal of Analysis.

[5] Rusyaman, E., et al., 2018, The convergence of the order sequence and the solution function sequence on fractional partial differential equation, Journal of Physics Conference Series, 983(1).

[6] Viliena, A. R., Rusyaman, E., Djauhari, E., 2019, Solusi Persamaan Diferensial Fraksional Non-Linear Menggunakan Telescoping Decomposition Method, Jurnal Matematika Integratif, Vol. 15(2), pp. 139-148.

[7] Ishteva, Mariya K., 2005, Properties and Applications of the Caputo Fractional Operator, Master Thesis, Department of Mathematics, Universität Karlsruhe.

[8] Podlubny, I. 1999, Fractional differential equations : an introduction to fractional derivatives, fractional differential equations, to methods of their solution and some of their applications, San Diego : Academic Press.

[9] Schiff J. L., 1999, The Laplace Transform: Theory and Applications, Springer-Verlag, New York.

[10] Zhou, J. K., 1986, Differential transformation and its application for electrical circuits (in Chinese), Wuhan: Huazhong University Press.

[11] Sonin, N. Y., 1869, On differentiation with arbitary index, Moscow Matem Sbornik, 6(1), 1-38.

[12] Samko, S. G., Kilbas, A. A., Marichev. O. I., 1987, Fractional Integrals and Derivatives and Some of Their Applications, Nauka $i$ Tekhnika, Minsk.

[13] Caputo, M., 1967, Linear models of dissipation whose Q is almost frequency independent II, Geophysical Journal International, 13(5), 529-539.

[14] Watugala, G. K., 1993, Sumudu transform: a new integral transform to solve differential equations and control engineering problem, International Journal of Mathematical Education in Science and Technology, Vol. 24(1), pp. 35-43. 
[15] He, J. H., 1998, Approximate analytical solution for seepage flow with fractional derivatives in porous media, Computer Method in Applied Mechanics and Engineering, Vol. 167(1-2), pp. 57-68.

[16] Gupta, V. G., Kumar, P., 2015, Approximate Solutions of Fractional Linear and Nonlinear Differential Equations Using Laplace Homotopy Analysis Method, International Journal of Nonlinear Sciences, Vol. 19(2), pp. 113-120. 
